\title{
PHAEOPHYSCIA ESSLINGERI SP. NOV. (PHYSCIACEAE, LICHEN-FORMING ASCOMYCOTA) - A NEW LICHEN SPECIES FROM EASTERN ASIA, WITH A WORLD-WIDE KEY TO THE HAIRY SPECIES OF THE GENUS
}

\author{
Sergii Y. KONDRATYUK K ${ }^{1,2 *}$, László LöKös ${ }^{3}$, Edit FARKAS ${ }^{4}$, Jung-Jae WOO ${ }^{2}$ and \\ Jae-Seoun HuR ${ }^{2}$ \\ ${ }^{1}$ M. H. Kholodny Institute of Botany, Tereshchenkivska str. 2, 01004 Kyiv-4, Ukraine; *ksya_net@ukr.net \\ ${ }^{2}$ Korean Lichen Research Institute, Sunchon National University, Sunchon 540-742, Republic of Korea \\ ${ }^{3}$ Department of Botany, Hungarian Natural History Museum, H-1431 Budapest, Pf. 137, Hungary \\ ${ }^{4}$ Institute of Ecology and Botany, Centre for Ecological Research, Hungarian Academy of Sciences, \\ H-2163 Vácrátót, Alkotmány u. 2-4, Hungary
}

Kondratyuk, S. Y., Lőkös, L., Farkas, E., Woo, J.-J. \& Hur, J.-S. (2016): Phaeophyscia esslingeri sp. nov. (Physciaceae, lichen-forming Ascomycota) - a new lichen species from Eastern Asia, with a world-wide key to the hairy species of the genus. - Studia bot. hung. 47(2): 251-262.

\begin{abstract}
Phaeophyscia esslingeri, a new species for science, is described from South Korea, Eastern Asia, compared with closely related taxa and illustrated with photographs. It is similar to Phaeophyscia hirtella, but differs by larger and light grey thallus, wider lobes, apothecia without a corona of dark rhizines around the base, shorter cortical hairs, and wider ascospores. Status of the hairy taxa of the genus Phaeophyscia from Eastern Asia is discussed. A world-wide key to hairy species of the genus Phaeophyscia is also included.
\end{abstract}

Key words: identification key, lichen-forming fungi, new species, South Korea, taxonomy

\section{INTRODUCTION}

Situation with the species concept of members of the genus Phaeophyscia as well as the foliose representatives of Physciaceae in the Eastern Asian region is more or less stable after careful revision done by KASHIWADANI $(1975,1984)$ and Moberg (1995), and after Park (1990) and Hur et al. (2005) in South Korea. However, some novelties were recently published (Hu and CHEN 2003, KONDRATYUK et al. 2013, 2014, 2015a, b, 2016a, b, etc.).

During a recent excursion to Gangwon-do Province of the Republic of Korea lichen specimens macroscopically similar to Physcia stellaris or P. aipolia, growing on trunks of solitary trees in open situations along the river, were collected. During identification in the laboratory they were found to be members of the very specific hairy group of the genus Phaeophyscia. However, it was found to be still an undescribed taxon. 
The aim of this paper is to provide the description of this taxon, which is described below under the name Phaeophyscia esslingeri.

\section{MATERIAL AND METHODS}

More than 100 Phaeophyscia specimens, collected during the last decade and deposited in the Korean Lichen Research Institute, Sunchon National University, South Korea (KoLRI), the Hungarian Natural History Museum (BP), and the Lichen Herbarium in the M. H. Kholodny Institute of Botany of National Academy of Sciences of Ukraine (KW-L) have been examined using standard microscopical techniques, and hand-sectioned under a dissecting microscope (Nikon SMZ 645; Nikon, Tokyo, Japan). Anatomical characters were observed using a Nikon Eclipse E200 microscope and a Zeiss Scope, complemented with a digital camera AxioCam ERc 5s. Sections of apothecia were tested with water, K, and IKI ( $10 \%$ potassium iodide). HPTLC analysis for chemical substances was applied in solvent system C according to Arup et al. (1993).

\section{RESULTS AND DISCUSSION}

Phaeophyscia esslingeri S. Y. Kondr., L. Lőkös, J.-J. Woo et J.-S. Hur, sp. nov. (Figs 1-4)

MycoBank nr.: MB 819385.

Similar to Phaeophyscia hirtella, but differs in having larger and light grey thallus, much wider and overlapping lobes, apothecia without dark rhizines around the base, much shorter cortical hairs, and wider ascospores.

Type: Republic of Korea. Gangwon-do, Jeongseon-gun, Nam-myeon, Nakdong-ri, Seonpyeong-gil, roadside trees along river, on bark of Populus nigra. Lat.: $37^{\circ} 19^{\prime} 16.28^{\prime \prime} \mathrm{N}$; Long.: $128^{\circ}$ 42' 53.84" E; Alt.: 360 m a.s.l. Coll.: Kondratyuk, S. Y., Lőkös, L. (163154_1), 16.09.2016 (holotype: KoLRI 041397, isotype: BP); the same locality, (163154_2) (isotype: KoLRI 041397); the same locality, on bark of Robinia pseudo-acacia, (163165) (isotype: KoLRI 041410); the same locality, growing together with Phaeophyscia sp. (163109) (isotype: KoLRI 41450).

Description: Thallus to $7(-10) \mathrm{cm}$ across, more or less rounded; lobes to 15-20 $\mathrm{mm}$ long and 4-7 mm wide, distinctly widened towards the tips, rather indistinct towards the centre, overlapping each other by marginal portions, better seen in peripheral zone, with somewhat undulating or uplifted rounded marginal portions; central portion sometimes somewhat knobby or warty or with microlobules to $0.2-0.3 \mathrm{~mm}$ across, more or less rounded; with white or hyaline hairs on upper surface of marginal peripheral zone of lobes, which sometimes can be sparse and/or broken; underside pale brown to dark brown or white towards the 
tips; underside with black rhizines (with whitish tips) to $0.3-0.5(-0.9) \mathrm{mm}$ long, rather thin to (35-)40-50 $\mu \mathrm{m}$ diam., somewhat brush-like, widened towards the tips. Thallus in section to $180-200 \mu \mathrm{m}$ thick, cortical layer to $35-40 \mu \mathrm{m}$ thick, paraplectenchymatous, separate cells to $7-10 \mu \mathrm{m}$ across observed; algal zone to (25-)40-80(-90) $\mu \mathrm{m}$ thick, algal cells to (10-)12-22 $\mu \mathrm{m}$ across; medullar to 75$80 \mu \mathrm{m}$ thick, white, lower cortical layer to $20-25(-30) \mu \mathrm{m}$ thick, light brown to dark brown, paraplectenchymatous, cells more or less rounded 7-12 $\mu \mathrm{m}$ across, somewhat smaller and darker (dark brown) towards the outer layer.

Apothecia to $1-4.5 \mathrm{~mm}$ diam., (in section to $0.35 \mathrm{~mm}$ thick), more or less rounded, on upper portion of thalline margin of apothecia with hairs to (40-) 70-150(-220) $\mu \mathrm{m}$ long, and to 20-30 $\mu \mathrm{m}$ diam. at the basis (better seen and more often on young apothecia, sparse on mature apothecia); in section lecanorine, thalline exciple to $150 \mu \mathrm{m}$ thick, cortical layer to (20-)40-60 $\mu \mathrm{m}$ thick, paraplectenchymatous; true exciple to $25-30 \mu \mathrm{m}$ thick in lateral portion and disappearing in basal portion or to $15-20 \mu \mathrm{m}$ thick if present; hymenium to 80 $\mu \mathrm{m}$ high; epihymenium 15-20 $\mu \mathrm{m}$ thick, yellowish brown, tips of paraphyses to 2.5-3 $\mu \mathrm{m}$ diam., ascospores Physcia-type, 1-septate, rarely 0 -septate ascospores observed too, greenish-blackish to dark brown, more or less attenuated at the ends and distinctly widened at the septum, (17-)18-25 × 10-12(-14) $\mu \mathrm{m}$ in water (40 measurements), and becoming somewhat wider in $\mathrm{K}, 18-27(-28) \times$ (11-)12-15(-15.5) $\mu \mathrm{m}$ in $\mathrm{K}$ (40 measurements).

Conidiomata on some thalli rather abundant as brownish spots, to $0.1 \mathrm{~mm}$ across, single and distant or aggregated; in section to $80-150 \mu \mathrm{m}$ in diam. and high; conidia lens-like or widely ellipsoid with attenuated ends, $2.5-3.5 \times 1.3-1.8 \mu \mathrm{m}$.

Chemistry: Cortical layer and medulla K-, C-, KC-. No substances were detected by HPTLC.

Distribution: It is hitherto known only from the type locality, where it is found to be rather abundant.

Etymology: It is named after the known American lichenologist Theodore Lee Esslinger (born in 1944), who had important contribution to taxonomy of the genus Phaeophyscia, and especially to taxonomy of the "hairy" species of this genus.

Taxonomic notes: Based on having cortical hairs on lobe tips and apothecial margin Phaeophyscia esslingeri is in intermediate position between two North American taxa, i.e. P. culbersonii Essl., and P. hirtella Essl., as well as the Eastern Asian P. hirtuosa (Krempelh.) Essl.* (known from Japan, Russia, and China).

\footnotetext{
* It should be mentioned that the original description of Phaeophyscia hirtuosa (as Physcia hirtuosa in KREMPELHUBER 1873) was very poor and without any measurements of thallus, thalline lobes, etc., except ascospores measurements. KASHIWADANI (1975) has not seen/investigated the type specimens of P. hirtuosa, while Physcia japonica (Hue) Vain. was put in synonymy with Phaeophyscia hirtuosa.
} 


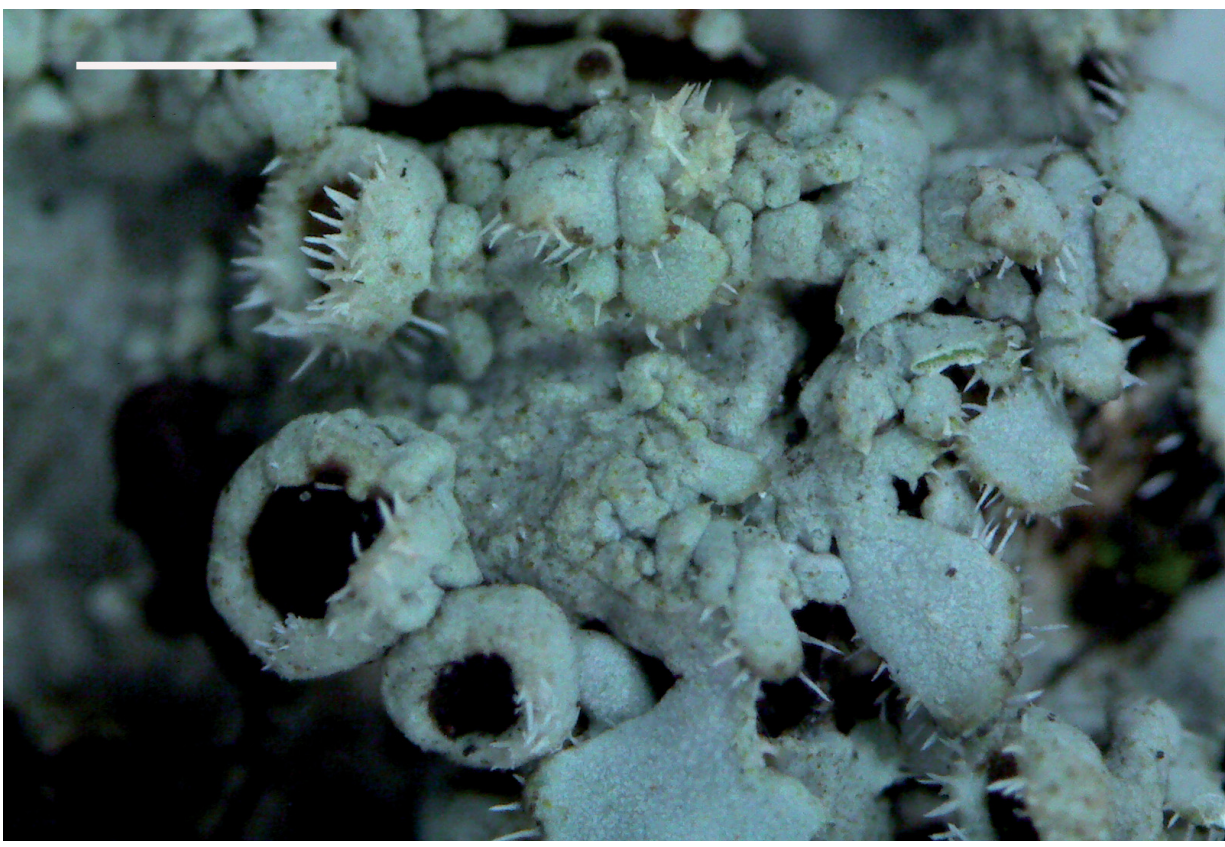

Fig. 1. General habit of Phaeophyscia esslingeri (holotype). Scale $1 \mathrm{~mm}$.

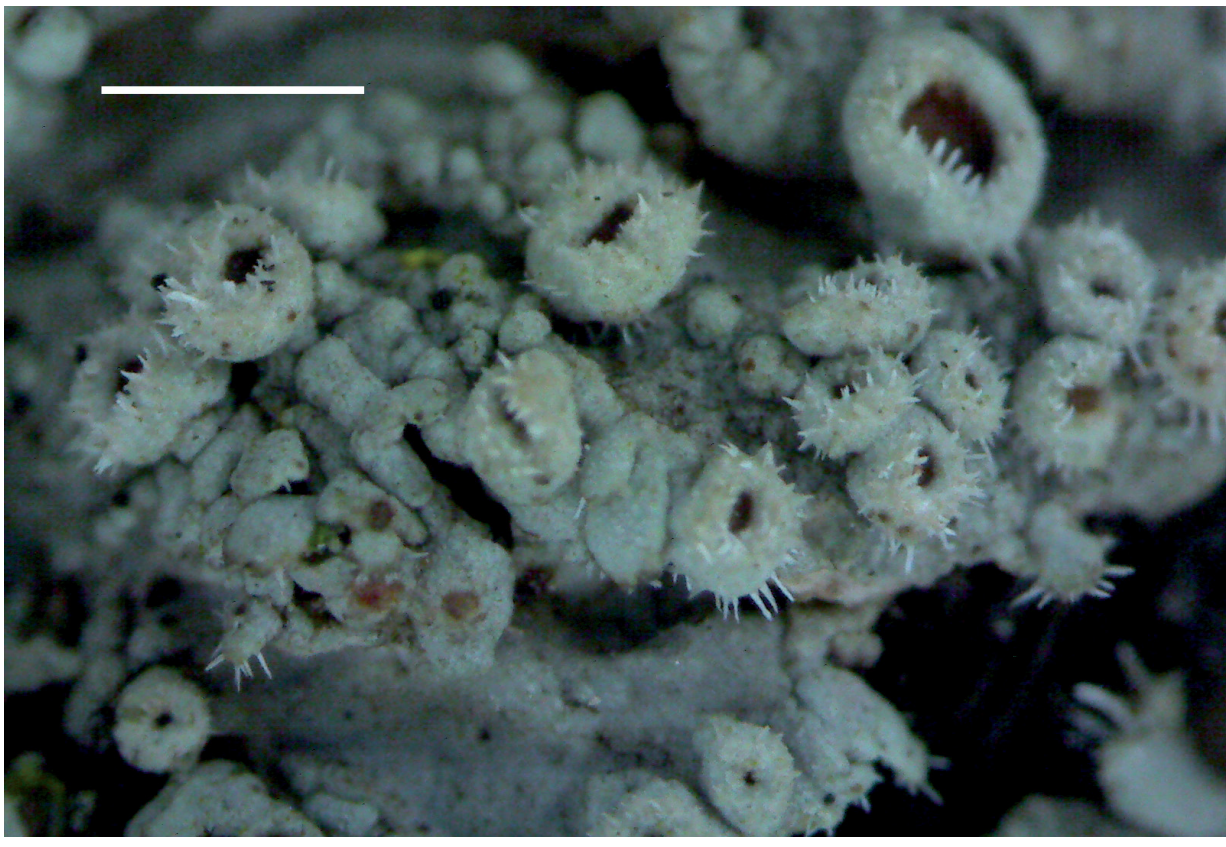

Fig. 2. General habit of Phaeophyscia esslingeri (holotype). Scale $1 \mathrm{~mm}$. 
However, cortical hairs of $P$. esslingeri are found to be shorter than in $P$. hirtella and $P$. hirtuosa, while they are longer than in P. culbersonii Essl.

Phaeophyscia esslingeri differs from $P$. hirtella in having larger and light grey thallus (to $7(-10) \mathrm{cm}$ across vs. $1-3(-4) \mathrm{cm}$ in diameter, greenish grey to dark grey or occasionally somewhat brownish); in having much wider and overlapping lobes (4-7 mm wide vs. $(0.3-) 0.5-1(-1.5) \mathrm{mm}$ wide, more or less linear and distant from each other), in having slightly shorter cortical hairs on lobe tips and apothecial margin $((40-) 70-150(-220) \mu \mathrm{m}$ vs. $0.05-0.2(-0.35) \mathrm{mm}$ long), in having apothecia without a corona of dark rhizines around the base, and in having wider ascospores $((17-) 18-25 \times 10-12(-14) \mu \mathrm{m}$ vs. $18-22.5 \times 8-10 \mu \mathrm{m})$, as well as in the lack of maculation of upper surface of thallus.

Furthermore, in having rather large thallus (to 5-10 cm across), apothecia of the same size (to $4 \mathrm{~mm}$ diam.), "hairy" apothecia, and thalline lobes, and in the lack of soredia or isidia, Phaeophyscia esslingeri is similar to the Eastern Asian species $P$. hirtuosa, usually growing on trunks of solitary trees or forest trees in open situations, as well as known from single asbestos roofs. It differs in having light grey upper side of thallus (vs. grey-brown to dark brown), much wider thalline lobes (vs. to $2 \mathrm{~mm}$ wide (after Moberg 1995), or 0.5-3.5 mm wide (after KASHIWADANI 1975), or (0.5-)1-3(-3.5) mm wide (after URBANAVICHYUS 2008)); in having subconvex thalline lobes with edges folded somewhat downward (vs. mainly concave lobes with ascending tips), in having shorter white cortical hairs on lobe tips and apothecial margin ((40-)70-150(220) $\mu \mathrm{m}$ vs. 0.2-0.3(-0.5) mm long (after KASHIWADANI 1984 and ESSLINGER 1978), and 0.5-1 mm long (after URBANAVichyus 2008), hyaline or darkening), in having brown lower side (vs. black), in having much shorter rhizinae (to $0.3-0.5(-0.9) \mathrm{mm}$ long vs. to $5 \mathrm{~mm}$ long (after Kashiwadani 1975)), in having much larger algal cells (12-22 $\mu \mathrm{m}$ vs. 5-8 $\mu \mathrm{m}$ diam.), and in the lack of "corona" of black rhizines on the lower part of thalline margin of apothecia, in having somewhat wider ascospores ((17-)18-25 × 10-12(-14) $\mu \mathrm{m}$ vs. (17-)19$23(-27) \times(7.5-) 9-11(-12) \mu \mathrm{m}$ (after Moberg 1995), while 20-25 × 8-12 $\mu \mathrm{m}$ (after KASHIWADANI 1975)), in the lack of prominent (distinctly projecting) marginal rhizinae (similar to eyelashes after URBANAVICHYUs 2008), as well as in the lack of projecting rhizinae appearing on the upper side, and in the lack of chemical substances (vs. small amount of atranorin, zeorin, leucotylin, Physcia-1 and Physcia-2 sensu Kashiwadani 1975).

Phaeophyscia esslingeri is similar to the North American species $P$. culbersonii Essl. - growing on bark or cactus stems, less often on rock - in having Physciatype ascospores, cortical hairs, and in the lack of a corona of dark rhizines on lower portion of thalline margin of apothecia, but differs in having larger whit- 
ish grey thallus (to $7(-10) \mathrm{cm}$ across vs. to $3-4 \mathrm{~cm}$ in diam., mostly grey-brown), in having much broader thalline lobes ( $4-7 \mathrm{~mm}$ wide vs. $0.6-1.5 \mathrm{~mm}$ broad), in the lack of epinecral layer (vs. more or less continuous and distinctive epinecral layer, which is distinctly patchy on the lobe ends (and therefore very pruinalike), in having longer cortical hairs on the lobe tips $((40-) 70-150(-220) \mu \mathrm{m}$ vs. up to $10-12 \mu \mathrm{m}$ long), in the lack of soredia, in having larger apothecia (to 4.5 $\mathrm{mm}$ vs. to $1.5 \mathrm{~mm}$ in diam.), in having almost the same ascospores ((17-)18-25 $\times 10-12(-14) \mu \mathrm{m}$ vs. $(16-) 18-25(-27) \times 8-12 \mu \mathrm{m})$ and in having smaller and widely ellipsoid conidia $(2.5-3.5 \times 1.3-1.8 \mu \mathrm{m}$ vs. $(7-) 8-12 \times 1 \mu \mathrm{m}$, cylindrical although frequently slightly bent near the middle) (EssLINGER 2004).

Phaeophyscia esslingeri is similar to the Japanese species P. spinellosa Kashiw., a newly described taxon known hitherto from Japan and Korea, to which KASHIWADANI (1984) included mainly all previous Japanese records of Phaeophyscia ciliata, in having large and whitish grey thallus, but it differs from $P$. spinellosa in having single-layer thallus more closely attached to the substratum (vs. richly irregularly dissected lobes seem to be curled or multilayered and loosely attached to the substrate); in having wider and convex thalline lobes (to 4-7 mm vs. to 1-2 mm wide, usually concave), in having pale brown or dark brown underside (vs. black), in having shorter and usually indistinct rhizines (to $0.3-0.5(-0.9)$ $\mathrm{mm}$ long vs. to $2 \mathrm{~mm}$ long, well distinct on uplifted lobe tips), in having larger apothecia (to $4.5 \mathrm{~mm}$ vs. to $2-3 \mathrm{~mm}$ across/diam.), in the lack of "corona" of black rhizines on underside of apothecia, and in having larger ascospores ((17-) 18-25 × 10-12(-14) $\mu \mathrm{m}$ vs. 15-18(-20) × 7-11 $\mu \mathrm{m})$ (KASHIWADANi 1984).

Similarly to Phaeophyscia hirtuosa, $P$. esslingeri is closely related to P. hirsuta (Mereschk.) Essl. and P. insignis (Mereschk.) Essl., which both are Northern Hemisphere taxa, because they all have apothecia with retrorse hairs and black lower surface of lobes. However, Phaeophyscia esslingeri, similarly to P. hirtuosa, can be clearly separated from the latter two species by the absence of soredia (see also in the key below).

Phaeophyscia esslingeri is similar to the North American and Japanese species $P$. imbricata (Vain.) Essl., known from montane deciduous broad-leaved forests in having secondary lobules, both paraplectenchymatous cortical layers and dark brown lower cortical layer, and in having Physcia-type ascospores, but it differs from $P$. imbricata in having larger thallus (to $7(-10) \mathrm{cm}$ across vs. $1-3$ $\mathrm{cm}$ diam.), wider thalline lobes (4-7 $\mathrm{mm}$ wide vs. $0.5-2 \mathrm{~mm}$ wide), in having lobules on the upper surface of central portions of thallus (vs. lobules marginal), shorter rhizines (0.3-0.5(-0.9) $\mathrm{mm}$ long vs. ca $3 \mathrm{~mm}$ long), in having larger algal cells (vs. 5-8 $\mu \mathrm{m}$ diam.), larger apothecia (to $4.5 \mathrm{~mm}$ diam. vs. to $2 \mathrm{~mm}$ diam.), retrorsely hairy thalline margin in both the upper and lower part of apothecia (vs. hairy only at the basis), in having retrorse hair on the upper surface of thal- 


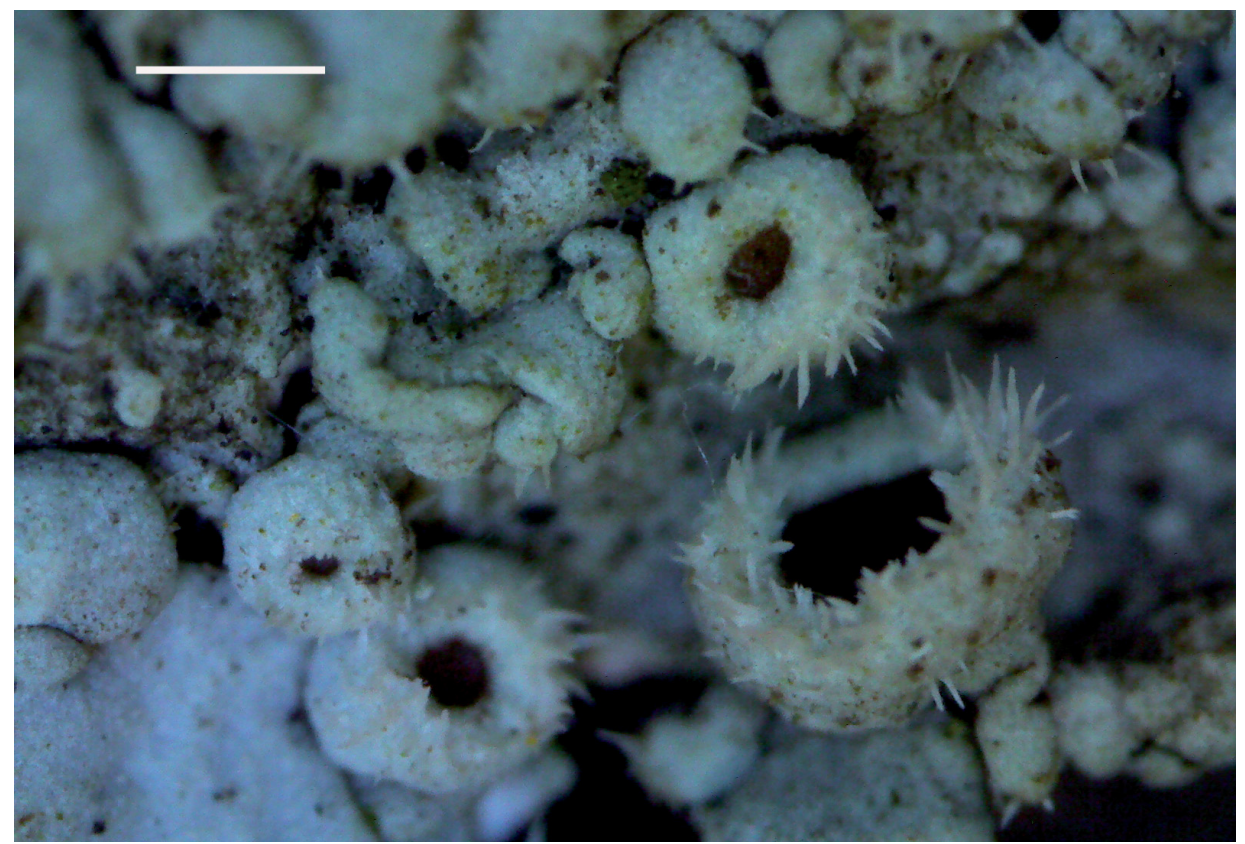

Fig. 3. Enlarged portion with apothecia of Phaeophyscia esslingeri (holotype). Scale $0.5 \mathrm{~mm}$.

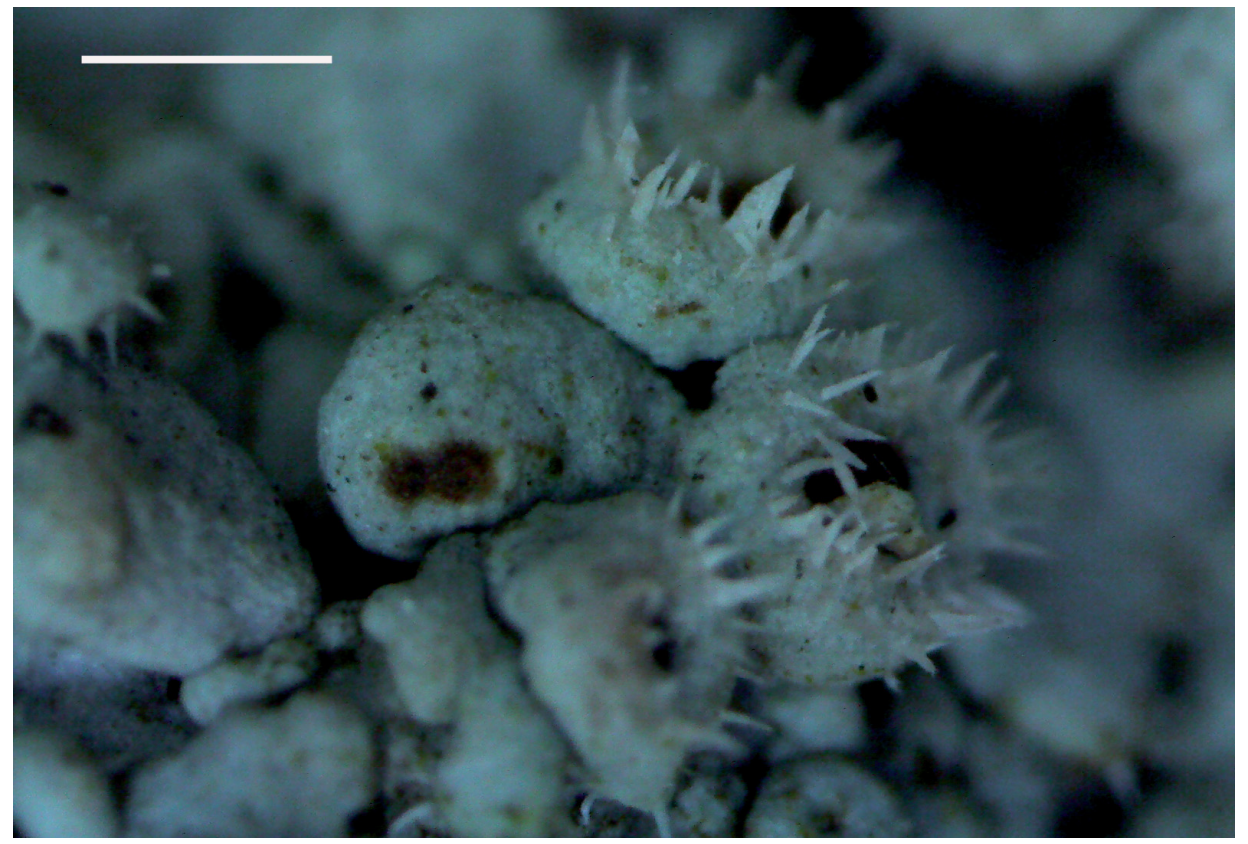

Fig. 4. Enlarged portion with apothecia and conidiomata of Phaeophyscia esslingeri (holotype). Scale $0.5 \mathrm{~mm}$. 
line lobes, in having wider ascospores ((17-)18-25 × 10-12(-14) $\mu \mathrm{m}$ vs. $18-23 \times$ 8-10 $\mu \mathrm{m})$ (data after KASHIWADANI 1975) or (18-)20-24(-27) $\times 9-11.5(-13.5)$ (after ESSLINGER 1978)).

Based on having dark lower surface, white medulla, and the lack of asexual propagules, Phaeophyscia esslingeri could be keyed out as P. ciliata (Hoffm.) Moberg, very common members of the genus Phaeophyscia in the Northern Hemisphere, occurring on bark or on moss over rocks. It differs in having larger thallus (to $7(-10) \mathrm{cm}$ across vs. usually less than $4 \mathrm{~cm}$ across), wider thalline lobes (4-7 mm wide vs. (0.2-) 0.5-1.5(-2) $\mathrm{mm}$ broad), in having cortical hairs on lobe tips and apothecial margin (vs. the lack of cortical hairs).

From the recently described Chinese species, Phaeophyscia hunana G. R. Hu et J. B. Chen, which was occasionally observed with sparse white cortical hairs (Hu and CHEN 2003) it differs in having larger thallus (to $7(-10) \mathrm{cm}$ vs. $2 \mathrm{~cm}$ in diam.), much wider lobes (4-7 $\mathrm{mm}$ vs. $0.3-0.5(-0.8) \mathrm{mm}$ wide), in having white medulla (vs. medulla red, $\mathrm{K}+$ purple), brown lower cortical layer (vs. lower surface black), in having larger apothecia (to $4.5 \mathrm{~mm}$ vs. $0.4-1(-2) \mathrm{mm}$ in diam.) in the lack of black rhizines around the basis of the apothecia, and in the lack of skyrin. Unfortunately, mature asci and ascospores, as well as conidiomata and conidia have not been seen by the authors of the original description (Hu and CHEN 2003).

However, KASHIWADANI (1975) provided detailed comments in the same paper on the type specimens of two infraspecific taxa of Physcia japonica (Hue) Vain., i.e.: P. japonica var. denigrata Vain. and P. japonica var. glaucocinerea Vain., which were carefully studied. From Kashiwadani's comments it is clear that the specimen of $P$. japonica var. denigrata (holotype preserved in TUR) may belong to Phaeophyscia hirtella, while Physcia japonica var. glaucocinerea Vain. is a member of the Phaeophyscia hirtuosa complex.

ESSLINGER (1978) included the isotype of Phaeophyscia hirtuosa (FH) in his revision, but he did not discuss measurements of ascospores of the type specimen, while he accepted Kashiwadani's opinion that Phaeophyscia japonica is a synonym of $P$. hirtuosa. However, results of ascospore measurements of the two taxa provided in original descriptions are very different. So KREMPELHUBER (1873) mentioned ascospores 17-19 × 6-7 $\mu \mathrm{m}$, while HuE (1900) provided ascospore measurements for Phaeophyscia japonica (as Physcia setosa Nyl. f. japonica Hue) as $22-27 \times 8-14 \mu \mathrm{m}$.

The probable conclusion that Phaeophyscia japonica and Phaeophyscia hirtuosa are conspecific was based only on the presence of the mainly whitish hairs (as setae in HUE 1900) of the same length, i.e. 0.2-0.5 mm long, while their size was not mentioned in the original Krempelhuber's description. It was mentioned by Esslinger as a confirmation that the North American taxon, i.e. Phaeophyscia hirtella had much shorter hairs. 
However, as far as ascospore measurements of the type specimen of Phaeophyscia hirtuosa were not especially checked and discussed, it is still possible that the Chinese Phaeophyscia hirtuosa and the Japanese material of "Physcia japoni$c a$ " are not conspecific. Therefore we propose to have two names for the Japanese and Chinese material until this question is not clarified. This illustrates that the question about the status of these two Eastern Asian taxa is still open.

Other specimens examined (paratypes): Republic of Korea. Gangwon-do, Jeongseon-gun, Nam-myeon, Nakdong-ri, Seonpyeong-gil, roadside trees along river, on bark of Populus nigra, growing together with Phaeophyscia sp. Lat.: $37^{\circ}$ 19' 16.28” N; Long.: $128^{\circ} 42^{\prime}$ 53.84” E; Alt.: 360 m a.s.l. Coll.: Kondratyuk, S. Y., Lőkös, L., 16.09.2016. 163154_3 (KoLRI 041399 sub Phaeophyscia sp.; BP); the same locality, growing together with Phaeophyscia sp., Rinodina sp., and Candelaria concolor 163153 (KoLRI 41396 sub Rinodina); the same locality on bark of Robinia pseudo-acacia, growing together with Phaeophyscia adiastola, 163162 (KoLRI 041407 sub Phaeophyscia adiastola); the same locality, growing together with Lecanora sp., Candelaria concolor, 163166 (KoLRI 041411 sub Lecanora); the same locality, on bark of Robinia pseudo-acacia, growing together with Phaeophyscia adiastola, and Endocarpon damaged by lichenicolous fungus, 163104 (KoLRI 041345 sub Endocarpon); the same locality, growing together with Phaeophyscia adiastola, and Endocarpon damaged by lichenicolous fungus, 163106 (KoLRI 041347 sub Endocarpon); the same locality, growing together with Phaeophyscia adiastola, and Lecanora, 163111 (KoLRI 041352 sub Lecanora); the same locality, growing together with Phaeophyscia adiastola, and Candelaria concolor, 163112 (KoLRI 041353 sub Phaeophyscia adiastola); the same locality, growing together with Phaeophyscia adiastola, 163114 (KoLRI 041355 sub Phaeophyscia esslingeri); the same locality, growing together with Phaeophyscia adiastola, and Endocarpon sp., 163132 (KoLRI 041373 sub Endocarpon); the same locality, growing together with Phaeophyscia adiastola, Candelaria concolor, and Endocarpon damaged by lichenicolous fungus, 163133 (KoLRI 041374); the same locality, growing together with Phaeophyscia adiastola, Candelaria concolor, and species of the genera Endocarpon and Lecanora, 163135 (KoLRI 041376 sub Lecanora); the same locality, growing together with Phaeophyscia adiastola, Candelaria concolor, and Agonimia sp., 163136 (KoLRI 041377 sub Agonimia); the same locality, growing together with Phaeophyscia adiastola, Candelaria concolor, Endocarpon sp., and Agonimia sp., 163137 (KoLRI 041378 sub Endocarpon); the same locality, growing together with Phaeophyscia adiastola, Candelaria concolor, and Endocarpon sp. damaged by lichenicolous fungus, 163138 (KoLRI 041379 sub Endocarpon). 


\section{World-wide key to the hairy species of the genus Phaeophyscia} (having cortical hairs on lobe tips and upper part of apothecial margins)*

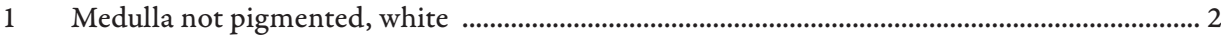

- Medulla pigmented orange-red ………………............................................................................ 10

2 Thallus with soredia or isidia ...................................................................................................... 3

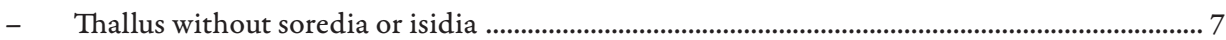

3 Cortical hairs on lobe tips very tiny (up to $10-12 \mu \mathrm{m}$ long and 1 cell thick) Phaeophyscia culbersonii Essl.

- $\quad$ Cortical hairs much larger (50-500 $\mu \mathrm{m}$ long and tapered from a slightly wider base), pale or darkening, sometimes also present on soredia or isidia

4 Hyaline or darkening hairs on isidia, much rarely on lobe surface; soredia/isidia on the lobe margins Phaeophyscia kairamoi (Vain.) Moberg

- $\quad$ Hyaline hairs on upper surface of thalline lobe close to tips; thallus with soredia ...................5

5 Soralia laminal capitate, usually broader than a lobe

Phaeophyscia insignis (Mereschk.) Moberg

- Soralia marginal Phaeophyscia hirsuta (Mereschk.) Moberg

6 Soralia lip-like at tips of ascending lobes

- Soralia elongated along the lobe ends (marginal). Cortical layer often with distinct epinecral layer, sometimes with uneven development making impression of patchiness

Phaeophyscia cernohorskyi (Nádv.) Essl.

7 Thallus large, to $4-7 \mathrm{~cm}$ across, lobes to $4 \mathrm{~mm}$ wide, overlapping by marginal portions ......... 8

- Thallus small to $1-3 \mathrm{~cm}$ across, lobes to $0.5-1 \mathrm{~mm}$ wide, more or less linear. Hairs on upper portion of thalline exciple of apothecium $0.05-0.2(0.35) \mathrm{mm}$ long. Cortical hairs sparse to numerous, the same long. Maculation on upper surface of thallus present

Phaeophyscia birtella Essl.

8 Ascospores small, 15-18(-20) $\times 7-11 \mu \mathrm{m}$; cortical hairs on apothecial margin constantly very sparse to almost absent; maculation on upper surface of thallus absent; on rocks

Phaeophyscia spinellosa Kashiw.

- Ascospores usually larger; cortical hairs on apothecial margin more or less dense; maculation on upper surface of thallus present; on bark of deciduous broad-leaved trees or conifers ..... 9

9 Hairs on upper portion of thalline exciple of apothecium $0.2-0.3(-0.5) \mathrm{mm}$ long, hyaline or darkening. Cortical hairs on the lobe ends absent. Maculation on upper surface of thallus present . Phaeophyscia hirtuosa (Krempelh.) Essl.**

- Hairs (40-)70-150(-220) $\mu \mathrm{m}$ long. Cortical hairs present while sometimes sparse and indistinct. Maculation on upper surface of thallus absent

Phaeophyscia esslingeri S. Y. Kondr., L. Lőkös, J.-J. Woo et J.-S. Hur

10 Ascospores Pachysporaria-type Phaeophyscia endococcinoides (Poelt) Essl.

- Ascospores Physcia-type Phaeophyscia erythrocarpa (Tuck.) Essl.

\footnotetext{
* All species of Phaeophyscia may have a "corona" of dark or black rhizines around the base of apothecia; these should not be confused with hyaline or white cortical hairs, which occur on both the upper part as well as the lower parts of the exciple.

** Status of Eastern Asian material is still unclear and correct name for this taxon still requires confirmation, see discussion in the text above.
} 
Acknowledgements - We are grateful to Mr Gi-Hyun Woo (Suwon, South Korea) for his kind help with field trip to Gangwon-do Province. This work was supported (for SK) in part by The Ministry of Education and Science of Ukraine (M/90-2015 and M/34-2016) and by Korean Brain Pool Program (161S-4-3-1659). HPTLC analysis was supported by the Hungarian Scientific Research Fund (OTKA K81232).

Összefoglaló: A Phaeophyscia esslingeri tudományra új zuzmófajt Dél-Koreából (Kelet-Ázsia) írtuk le. Kinézetre hasonló a $P$. hirtella-hoz, de a nagyobb méretű és világosszürke színű telepe, a rövidebb felszíni szőrök a telep szélein, a sötét rhizinákból álló ún. korona hiánya az apotéciumok alján, továbbá a szélesebb aszkospórák alapján jól elkülöníthető attól. Részletesen tárgyaljuk más, közel rokon taxonoktól való megkülönböztető bélyegeit. A fajleírást a holotípusról készített fotók és egy határozókulcs egészíti ki.

\section{REFERENCES}

Arup, U., Ekman, S., Lindblom, L. and Mattsson, J.-E. (1993): High performance thin layer chromatography (HPTLC), an improved technique for screening lichen substances. - $L i$ chenologist 25(1): 61-71. http://dx.doi.org/10.1017/s0024282993000076

Esslinger, T. L. (1978): Studies in the lichen family Physciaceae II. The genus Phaeophyscia in North America. - Mycotaxon 7: 283-320.

Esslinger, T. L. (2004): Phaeophyscia. - In: Nash III, T. H., Ryan, B. R., Diederich, P., Gries, C. and Bungartz, F. (eds): Lichen flora of the Greater Sonoran Desert Region. Vol. 2. Lichen Unlimited, Arizona State University, Temple, Arizona, pp. 403-414.

Hu, G.-R. and Chen J.-B. (2003): The lichen family Physciaceae (Ascomycota) in China IV. A new species of Phaeophyscia. - Mycosystema 22(4): 534-535.

Hue, A. (1900): Lichenes extra-europei a pluribus collectoribus ad Museum Parisiensi missi. Nouv. Arch. Mus. Hist. Nat. Paris 3: 21-196.

Hur, J.-S., KoH, Y. J. and HARADA, H. (2005): A checklist of Korean lichens. - Lichenology 4(2): 65-95.

Kashiwadani, H. (1975): The genera Physcia, Physconia and Dirinaria (lichens) of Japan. - Ginkgoana 3: 1-77.

Kashiwadani, H. (1984): A revision of Physcia ciliata (Hoffm.) DR. in Japan. - Bull. Nat. Sci. Mus. Tokyo, ser. B, 10: 43-49.

Kondratyuk, S. Y., Lökös, L., Tschabanenko, S., Haji Moniri, M., Farkas, E., Wang, X. Y., OH, S.-O. and Hur, J.-S. (2013): New and noteworthy lichen-forming and lichenicolous fungi. - Acta Bot. Hung. 55(3-4): 275-349. https://doi.org/10.1556/abot.55.2013.3-4.9

Kondratyuk, S. Y., Lökös, L., Kim, J. A., Jeong, M.-H., Kondratiuk, A. S., OH, S.-O. and Hur, J.-S. (2014): Kashiwadia gen. nov. (Physciaceae, lichen-forming Ascomycota), proved by phylogenetic analysis of the Eastern Asian Physciaceae. - Acta Bot. Hung. 56(3-4): 369-378. https://doi.org/10.1556/abot.56.2014.3-4.12

Kondratyuk, S. Y., LöKös, L., FARKas, E., OH, S.-O. and Hur, J.-S. (2015a): New and noteworthy lichen-forming and lichenicolous fungi 2. - Acta Bot. Hung. 57(1-2): 77-141. https://doi.org/10.1556/abot.57.2015.1-2.10

Kondratyuk, S. Y., Lőkös, L., FArkas, E., OH, S.-O. and Hur, J.-S. (2015b): New and noteworthy lichen-forming and lichenicolous fungi 3. - Acta Bot. Hung. 57(3-4): 345-382. https://doi.org/10.1556/034.57.2015.3-4.7 
Kondratyuk, S. Y., Lökös, L., Halda, J. P., Haji Moniri, M., Farkas, E., Park, J. S., Lee, B. G., OH, S.-O. and HuR, J.-S. (2016a): New and noteworthy lichen-forming and lichenicolous fungi 4. - Acta Bot. Hung. 58(1-2): 75-136. https://doi.org/10.1556/034.58.2016.1-2.4

Kondratyuk, S. Y., LöKös, L., Halda, J. P., Upreti, D. K., Mishra, G. K., Haji Moniri, M., Farkas, E., Park, J. S., Lee, B. G., Liv, D., Woo, J.-J., Jayalal, R. G. U., Oh, S.-O. and HUR, J.-S. (2016b): New and noteworthy lichen-forming and lichenicolous fungi 5. - Acta Bot. Hung. 58(3-4): 319-396. https://doi.org/10.1556/abot.58.2016.3-4.7

Krempelhuber, A. von (1873): Chinesische Flechten. - Flora (Regensburg) 56: 465-470.

Moberg, R. (1995): The lichen genus Phaeophyscia in China and Russian Far East. - Nord. J. Bot. 15: 319-335. https://doi.org/10.1111/j.1756-1051.1995.tb00158.x

PARK, Y. S. (1990): The macrolichen flora of South Korea. - Bryologist 93: 105-160. https://doi.org/10.2307/3243619

Urbanavichyus, G. P. (2008): Phaeophyscia. - In: Andreev, M. P. et al. (eds): Handbook of the lichens of Russia. 10. Agyriaceae, Anamylopsoraceae, Aphanopsidaceae, etc. Nauka, SanktPetersburg, pp. 222-253.

(submitted: 13.10.2016, accepted 30.11.2016) 